\title{
Why Should Parliaments Continue to Debate?: The Intertwined Virtues of Parliamentary Debates
}

\author{
Olivier Rozenberg, Sciences Po
}

\begin{abstract}
Parliamentary debates may seem as anachronistic today given their limited role in forging majorities within parliaments. Yet, this paper seeks to demonstrate that they still play a diversity of other roles. They contribute to frame ideologically a debate and therefore to link policy proposal to electoral politics. They can also be regarded as ways of both controlling and motivating members. They bring credibility to the view that parliaments are representative - feeding people mimetic relations to politics. Last, they help implementing the accountability process forcing ministers to speak, to listen to criticisms and to answer them. Those four aspects, based on a variety of literature, are considered to be still relevant in the contemporary period.
\end{abstract}

Keywords: Parliaments, debates, rhetoric, democracy, representation

Parliament is the institution of speech. The Latin verb "parabolare," the origin of the word, does not mean simply "to speak" but rather "to tell stories". Parliament is the place where politicians transform information, action and conflicts into narratives. Historically, the establishment of freedom of speech has been one of the first steps in building parliamentary institutions. For a long time, the aim of speeches in Parliament was taken for granted. Legislatures were the main locus for policy-making, and statements by Members of Parliament (MPs) helped to perform this collective task. In addition, MPs mainly acted as trustees, independent from their voters and/or their parties. They could be convinced by their colleagues and change their minds over the course of a debate. The quality of speakers was therefore a key dimension in parliamentary 
activities. As Roussellier (1997) demonstrated in his study of the post-World War I French low chamber, eloquence in the debates played a great role in the passage of laws and in cabinet survival.

The role of parliaments in European political systems changed progressively throughout the 20th century. Although some legislatures are more influential than others (Sieberer, 2011), today's parliaments are less crucial in defining the general orientations of domestic law. The personalisation of politics and the presidentialisation of political systems contribute to this trend, which is not limited to presidential or semi-presidential regimes but also to parliamentary democracies (Poguntke and Webb, 2015). Furthermore, and crucially, MPs' have become less autonomous during the process decision-making. They are whipped by their party leaders. Their room for manoeuvre is bounded by party platforms and coalition agreements. Lastly, the convergence of mass media and digitalisation potentially exposes many activities to public view. Any acknowledgment by an MP that he was wrong and his colleagues were right can be made available to the public and alter the representative's credibility. Under these circumstances, the view that MPs can convince each other through the internal quality of their views appears at best naïve (Ferrié et al., 2008). An in-depth field study related to debates organised within the French National Assembly concluded that such genuine deliberative moments were indeed extremely rare (Viktorovitch, 2013). It is also evident to any visitor of European legislatures that as bills are passed, most attending MPs do not listen to their colleagues. They once read newspapers; now, they type on their smart phones.

This centary trend calls into question the present utility of parliamentary debates. What is the point of speaking before decision-making if most decisions have already been set? Why should MPs articulate claims to support their views if those views are (essentially) defined by their belonging to a given political party? And why should MPs continue to speak when their colleagues - and even, as is usually the case, their voters - do not listen? This paper defends the view that although parliamentary debates rarely help to frame a majority within assemblies nowadays, they fulfil diverse other ends. Those ends are divided into four functions, here considered successively. They deal with improving the stability of decisions, improving the quality of legislators, legitimatising power and moderating it. The remarkable diversity of those aims, and even their at times contradictory nature, have much to say about the multifunctional nature of legislatures and their unique contribution to addressing collective action problems within representative democracies. Pluralist, public and continuous debates therefore constitute a distinctive way in which parliaments can institutionalise conflict within society.

This analysis focusses on parliamentary rather than other kinds of political discourses. Indeed, the political rhetoric employed in parliamentary chambers has particularities stemming from the institutionalisation of pluralism. First, 
it is controlled by procedure. It is also pluralistic, public, ritualistic and functional to the extent that it often lays the groundwork for adopting a law. Furthermore, from the parliamentary speaker's perspective, the session provides an original synthesis of the legal guarantee of broad freedom of expression and the procedural imposition of a particular order to control the expression of emotions (Heurtin, 1999). By offering a unique combination of these various properties, the session helps distinguish political parliamentary rhetoric from that expressed in a pamphlet, on the podium at party conferences or during a televised debate. This paper seeks to demonstrate that the combination of these particular properties helps parliamentary debates offer concrete solutions to various problems related to the quality of the decisions and of the decisionmakers in a representative regime ${ }^{1}$. As it will be developed, social choice theory, the sociology of elites, political psychology and democratic theory address these problems, which revolve around the sustainability of collective decisionmaking, the quality and motivation of elected officials, the overall legitimacy of the political system, and the moderation of power. No silver bullet could resolve these major challenges. However, parliamentary sessions merit consideration and even defense as an institutional technique seeking to reconcile the efficiency, legitimacy and moderation of power. After examining the virtues of parliamentary debates with regard to the stabilisation of political decisionmaking, this paper will consider their positive effects on the quality of representatives in terms of their intrinsic competence one the one hand, and legitimacy on the other hand. A final part will analyse the effects of parliamentary debates on moderating political power.

\section{Reducing the Chaos of Parliamentary Decision-Making}

The first argument posits that deliberation improves the quality of decisionmaking; the other parts will focus more on the decision-makers and the political system. A collective decision is considered to be better if those who made it do not immediately call it into question. This first part accordingly seeks to demonstrate that the debate preceding a decision enhances the latter's sustainability. As Condorcet (1986) first intuited, we know that the aggregation of individual preferences is uncertain. Notable among social choice theory's many findings is that an assembly of peers asked to decide issues by simple majority voting tends to yield unpredictable and unstable results given the multidimensionality of these issues (Plott, 1967; McKelvey, 1976). A majority formed on the basis of one dimension - social protection, for example - might be undone, within the same group, by a majority concerned with another dimension, such as cost reduction. The specialised literature on this subject, mainly 
the highly formal work of economists, therefore considers the dimensionality (i.e. the number of dimensions) of choice as a central notion.

Solutions to the stability problems of aggregate decision-making arise in collective bodies are often considered through the procedural lens (Crès, 2018). Specific procedures may indeed reduce the dimensionality of the issues under debate (Shepsle, 1979). Having legislation examined by committees organised according to sectors of public action, and then voting on it article by article rather than as a whole, allow for issues to be sorted out to some extent. Another institutional technique consists of introducing high qualification thresholds for a majority (Greenberg, 1979). In practice however, it has been seldom used outside of constitutional revisions or votes of censure.

The highlighting on procedures by social choice theorists has led to the neglect of the contribution of debates to the stabilisation of parliamentary decisions. At first sight, debates, speeches and rhetorical effects may be viewed as a factor of instability rather than stability. It is true that performances, as defined by performance studies (Schechner, 2002), occasionally create unexpected decisions within assemblies. In 1992 in the French National Assembly, for instance, an MP from the Gaullist right convinced half of his group to oppose the Maastricht treaty thanks to the convincing power of his words (Rozenberg, 2018). Yet such events hardly ever occur nowadays and should not hide the fact that the decision of an assembly whose members have previously announced their choice is more predictable and durable than a decision that is not orally justified. Speaking before voting also allows elected officials to both make their choice known and clarify the dimensions of the debate on which it is based.

Parliamentary debate most often takes the routine form of a confrontation between the majority and the opposition. The session's debate then allows for arguments supporting or opposing the government. As Kari Palonen has written: "Pro et contra debate is not merely tolerated in, but presupposed by parliamentary politics as a condition for dealing with the items on the agenda in a 'parliamentary' manner" (2014: 11). In other words, public debate narrows the framework of the debate down to a choice between support and opposition to the government. This tendency towards confrontation that led Jean-Jacques Rousseau to be wary of the factiousness of deliberative assemblies is reminiscent of group polarisation phenomena observed in social psychology research (Manin, 2011). The proclivity of deliberative groups to radicalise their positions can thus be understood as a process to make issues salient during debate, and thereby to stabilise the majority decision.

More broadly, session debates enable the expression of conflicting ideologies whose role in terms of reducing dimensionality is demonstrated, in terms of ordinary citizen votes, in Hinich and Ordeshook's formulation of a spatial model of voting (see in particular: Enelow, Hinich, 1984). The ideology that is 
likely to interlink the dimensions of an issue is not definitively set in electoral programs during campaigns; it is both reaffirmed and adapted during the parliamentary term via debates in the chamber, through confrontation with the legislative agenda on the one hand, and with the discourse formulated by the opposing side on the other. In a period where ideologies are supposed to be declining, parliamentary debates may even find a renewed utility. Indeed, as political views are not given any more on many issues, debates are an opportunity (and often a duty) for parties to articulate their views on a given topic within a larger conception of society. A vote in parliament forces parties to take positions, but a preliminary debate is a strong incentive for linking this position with more general views.

Speaking before voting increases the likelihood of reaching agreement but does not guarantee it. In order to limit the potentially disrupting effects of rhetoric, legislative debates in parliament are organised according to two principles: the shift from the general principal to the specific components on the one hand, and the ordered discussion of articles on the other hand. According to Bentham (2002), debates are indeed supposed to be organised in such a way as to prevent the discussion from veering towards any other subject than the one being debated. The need to ensure this via specific procedures indicates how difficult it is to achieve.

While the oral procedure in parliaments helps improve the quality of decisions, its retention in modern democracies is probably due to other factors related to the quality and legitimacy of parliamentarians and the moderation of power. More specifically, while the discursive solution might be less efficient than the procedural solution in producing robust decisions, it has the advantage of being able to simultaneously seek other common goods, on which the remainder of this paper will focus.

\section{Improving the Behaviour of Parliamentarians}

Parliamentary debates indirectly contribute to the quality of democratic decisions by improving the quality of parliamentarians. While the next part will consider their relational quality, through their legitimacy, this section will consider their intrinsic qualities, that is, the behaviour of representatives. It argues that debate improves parliamentarians' behaviour in two ways: it places them in the public eye and it motivates them.

First, session debates allow voters to better know their representatives. As Jon Elster (2013) notes, this idea is crucial to the thinking of the English philosopher Bentham. According to Bentham, it is foolish to try to select politicians with moral qualities: better to select a procedure that makes it in their 
interest to behave well. The complete publicity of the sessions reflects this concern; parliamentarians are supposed to act under the supervision of the "Tribunal of Public Opinion". The very existence of parliamentary debates can be interpreted as a system for monitoring elected officials. MPs' membership in a group and the regular recording of their votes certainly provide important, and even critical information about their behaviour. However, these elements remain relatively undiscriminating given the size of the groups. By contrast, statements made during sessions offer more insight into the attitude of each representative ${ }^{2}$.

Moreover, publicly argued explanations for a vote strengthen the commitment of MPs to their position. Sophisticated tactics consisting of voting differently as the legislative procedure progresses become costlier. The compromising power of public debate thus underscores the paradox raised by Bjorn Erik Rasch (2014): parliamentarians almost always abandon insincere behaviour, even when it would be in their interest to pursue it in order to bring the final decision closer to their interests. It is true that publicity almost forces MPs to stick to their position and make it much more difficult to appear as being convinced. Yet, what is lost in terms of deliberative quality of the debates may be a price to pay for the stability and coherence of MPs' views ${ }^{3}$.

In a system where activities are delegated at each step of the representative system (Strøm, et al., 2003), oral statements made in session are the only type of institutionalised behaviour that is impossible to delegate without losing ownership (Rozenberg, Martin, 2011). Session votes are often delegated to colleagues on duty, sometimes at the cost of legal circumvention. The drafting of reports is either partially or completely outsourced to discrete clerks. Written questions, private members' bills and amendment proposals are often drafted by assistants. Even if others often prepare the speeches, taking the floor in session physically and directly involves MPs. It is a greater basis for judgment by a third party - not just an abstract and often fairly indifferent voter, but also party leaders. Among other criteria, the latter assess the merit of MPs by their debating skills in session. For example, an analysis of debates in the European Parliament has concluded that despite the public's indifference, its members take the floor to promote themselves: to explain themselves to their colleagues or curry favour with national party heads, on whom their reelection mainly depends (Slapin, Proksch, 2010). In parliamentary regimes where government members mainly come from the Parliament, the political capital of potential future ministers is built progressively over the course of public sessions by patiently demonstrating ability as a speaker, and also loyalty, composure, sympathy, abnegation, etc. This slow incorporation of behavioural norms is also an indirect - as discreet as it is unrelenting - means by which the Parliament exerts control over the government (Saalfeld, 2000). 
Second, parliamentary debates help motivate elected officials to fully carry out their duties. Here again, Bentham's analysis, as illuminated by Elster (2013), points to the persistence and seriousness of the free-rider issue that assemblies face. Parliaments run the risk of seeing their members turn away from parliamentary duties given that what they need to do to become members of the assembly is distinct from their duties as members: to get elected in the first case, and to legislate and control the government in the second. In view of this discrepancy, public sessions can be seen as an incentive and reward system for parliamentary mobilisation by enabling representatives to stand out as individuals. Since only peers and ministers are involved, the sessions provide concrete evidence of the positive exclusivity of belonging to the parliamentary club. With the help of decorum, they suggest, perhaps illusively, a certain social prestige. Many tales from MPs often describe a particular feeling that they experienced when they first entered the chamber, and then when they took the floor for the first time ${ }^{4}$. The gradual expansion of the right to speak in the chamber, under the whips' supervision, is in fact part of the parliamentary cursus honorum.

The hypothesis that parliamentary debates encourage representatives to fulfil their duties is all the more plausible given that public speaking plays an important role in their selection. To get elected, candidates must know how to speak in a way that convinces and charms. It is therefore not unreasonable to assume that members of Parliament have some talent and even some taste for public speaking. By requiring of MPs the same type of skills as those that were necessary to them as candidates, parliamentary debates help reduce the gap between the pre- and post-election periods that accounts for the bulk of Parliament's free-riding problem. Studies have empirically confirmed the appeal of sessions - even if there are important exceptions. Some representatives specialise in speaking on the floor, such as the "ideologues" or "generalists" in the British Commons (Searing, 1994), the "animators" in the European Parliament (Navarro, 2009) and the "show horses" in in the Austrian National Council (Jenny, Müller, 2012). Session debates also provide an opportunity for both the experts and generalists among the representatives to speak to each other. In this sense session debates can be understood as a system aiming to limit public policy fields' capture by experts.

In addition to a relish for giving speeches on the floor, MPs and senators have an interest in speaking. Indeed, parliamentary debates allow elected officials to deliver messages to the public in general, and to their voters in particular (Mayhew, 1974). Debates are indeed a tool of communication to the public. Having the leeway to address different audiences during debates is all the more valuable that whips closely supervise the final vote. Indeed, the tactical and psychological benefits of session debates are clear in the case of backbenchers subjected to voting discipline. To speak "against" before voting "for" 
a bill allows members to soothe frustration and issue a warning to the government. Nicolas Roussellier (1997) thus refers to the critical tone used towards the French President of the Council Clemenceau during the 1919 censure debates by MPs who were afraid the public would hold them responsible for his fall. Today, the media's weak interest is conducive to dissenting words when dissenting vote is more difficult to contemplate, insofar as it can jeopardise the adoption of a text and therefore make headlines in the news. In many respects closed meetings of parliamentary party groups also, and better, fulfil both psychological and tactical functions. The voicing of protest in session is understood as a gradation in internal disagreement. Moreover, the management of parliamentary groups, which many accounts indicate cannot be exclusively authoritarian (Carcassonne, 1993), often makes it necessary to allow for a certain freedom of speech. Research has shown, for instance, that speeches made in the European Parliament enable the expression of dissent on a national basis (Proksch, Slapin, 2010) while the groups' level of cohesion during votes is particularly high (Hix, et al., 2007).

Parliamentary debates thus contribute to voting discipline in two ways: public speaking is both an outlet for dissatisfied representatives and an individual's compensation for collective mobilisation that group leaders grant in exchange for compliant behaviour ${ }^{5}$. The political steering of a parliamentary group consists precisely in maintaining group cohesion by using both of these methods, one coercive and the other allaying. An ambitious comparative work focusing both on the rules related to the access to the floor and the electoral rules has brought confirmation of the key role played by parliamentary debates in enforcing party discipline (Proksch, Slapin, 2014). It appears indeed that when the electoral rules are more favourable to personal votes, MPs tend to be less controlled regarding parliamentary speech.

\section{Legitimating Representative Government}

Besides improving the actual behaviour of members of Parliament, debates are channels of political legitimation because they directly or indirectly contribute to establishing the claim of MPs and senators that they represent society. This claim rests on precarious empirical and theoretical grounds. The electorate's progressive democratisation has not translated into an equivalent democratisation of representatives. The sociological gap between representatives and the represented has widened in all of Europe's democracies since 1945 (Best, Cotta, 2000). The professionalisation of political activities has further widened the divide (Offerlé, 1999). More generally, popular elections are an uncertain means of legitimation, not only because they create losers, but also because 
they partially subscribe to an aristocratic philosophy - the selection of the best - rather than a democratic one - the selection of fellows (Manin, 1997). Finally, the idea that elected officials represent the territory from which they come sits awkwardly with the district's inevitable social diversity. This observation led Alessandro Pizzorno (2008) to write that the electoral mandate must be "imaginary"; it is not fictitious, but rather fictional insofar as it is based on collective imagination, that is, symbolic production. Indeed, as stated and denounced by Pierre Bourdieu (1981), political domination is primarily built on a symbolic power grab - a manipulation of meaning.

Chamber debates are precisely symbolic reservoirs from which political professionals draw to lend credibility to their claim of speaking for the laymen. Delphine Gardey (2013) has demonstrated this by comparing French and British reporting procedures at sessions in the 19th century. The former's activism and latter's reluctance to produce and get media attention for reports of the debates indicate that the desire to assert an uncertain political legitimacy trumps the parliamentary organisation's concerns with spreading its minutes throughout society. Here again, decorum and parliamentary rites aim to lend credibility to the claim of representativeness. At a more detailed level, we observe that parliamentary speech and its rhetorical devices are useful to this symbolic production given their remarkable range. Depending on the set-up, a member of Parliament might claim to speak in the name of a social group or specific territory, or via increased generalisation, of the whole nation. By contrast, the discourse of a minister or a national party leader mostly if not completely precludes such focal changes. Lexicometric analyses of parliamentary debates also reveal forms of subtext in official speeches increasing the status of a number of parliamentary figures (de Galembert 2013; Vigour 2013). Similarly, praxeological and ethnomethodological analyses highlight the extensive "dialogical networks" of which parliamentary debates are a part (Bayley, 2004; Dupret, et al., 2007; Ferrié, et al., 2008). Back-and-forth arguments between society and Parliament testify to both MPs' propensity to (re-) create "absent audiences", and their power to connect to them through words. All in all, according to these analyses "[...] parliamentary deliberation creates a contingent and temporary structure for social organization" (Dupret, et al., 2007: 43).

In sum, the floor helps MPs claim they are representatives by allowing them to assert it loud and clear in the hopes of being heard by the represented. If the body was only convened to vote, or if it only deliberated in secret, the artificiality of the representative mechanism would be more obvious. Moreover, as Jürgen Habermas (1984) has argued, the ripples of parliamentary debates play a central role in the public sphere: they can help citizens form opinions, become interested in public problems or in short to deliberate amongst themselves. 
By contributing to a political identification process for citizens, debates are part of the mimicry that characterises representative government according to the French philosopher Jean Claude Milner. Debates feed the appetite of the represented to put themselves in the position of the representatives. They maintain the illusion that a reversal of positions is possible. Indeed, by offering a mimetic show, politicians seek to make its domination acceptable: "In many modern regimes, mimicry makes the constraint of imposing a divide between the governing and the governed bearable" (Milner, 2011:63). Since the function of the politicians' show is to feed into laymen conversations (rather than impress them, for example), it must include a strong discursive dimension. MPs speak in order to be spoken of. Because of their publicity, institutionalisation, everyday nature and rites, parliamentary debates provide an exceptional material to feed such mimetic legitimation.

As was the case for the stabilisation of collective decisions and the improvement of parliamentary behaviour considered above, the legitimisation of MPs through debate is a partial and often deficient solution. It is locked in a structural contradiction: the members of Parliament's denial of the representative gap clashes with the scale of the symbolic manipulation system designed to deny it. Parliamentary decorum seeks to lend credibility to the chamber's claim to bring out the voice of the nation, but its gilding and velvet simultaneously indicate that the sessions are conducted amongst the privileged. Similarly, parliamentary speech seeks to convince of the legitimacy of MPs, but successfully pursuing this rhetorical work implies skills that are unequally distributed in society and calls for a form of professionalism. In short, claiming to represent the people involves distinguishing oneself from them in practice.

When no more than a third of the population trusts the national parliament in any member state of the European Union (Rozenberg and Hefftler, 2015), should we conclude that parliamentary sessions are losing their legitimising properties? Given the relish of citizens interviewed in focus groups for explanations of parliamentary debates, especially question time, the answer appears to be rather negative (Rozenberg, 2013). Even if they are criticised, these debates can contribute to political identification processes ${ }^{6}$. Furthermore, Elster's (2013) analysis of Bentham underscores that the English philosopher was concerned that the people judge their leaders rather than each other. Nowadays, unlike in Bentham's time votes are public for MPs but secret for citizens. According to this logic, the anti-parliamentarianism stirred by parliamentary debates can be understood as a discreet way of contributing to civil peace by redirecting resentment towards a faraway elite rather than towards a neighbour? ${ }^{7}$. 


\section{Moderating Power}

The imperfect contribution of parliamentary debates to the legitimisation of elected officials can also be explained by the contradiction between this purpose and that of limiting absolute power. Indeed, this last section aims to demonstrate that the institutionalisation of pluralistic and even contradictory speech is a discursive process for limiting authoritarianism. Developed by the theoreticians of political liberalism, modern anti-absolutist processes primarily focus on the law and show a certain degree of sophistication: the idea is to distinguish institutions according to how they relate to the law, to hierarchise the latter and even ring-fence its essential part via the control of constitutionality. By contrast, assembly practices can be understood as a pre-modern (Hébert, 2018), if not prehistoric (Testart, 2012), effort to limit excessive power. This effort is not an abstraction like the separation of powers, but rather a practical system of power figuration based on the three unities of classical theatre 8

Parliamentary debates are not only forums for the representation of power, but also for the limitation of this power in two ways. First, they force authorities to continuously speak under conditions that govern them. Since the experience of totalitarianism, it has been known that the language and words of power are not necessarily moderating forces. Yet, as expressed in Kafka’s work, impunity thrives off of silence. As Pierre Clastres (1972 and 1989) observed in his studies of pre-Columbian societies, requirements that the tribal chief speak are an effective means of preventing excesses of power: "the requirement that whenever possible a non-coercive instrument - language - be used subjects the chief to the group's constant monitoring: any word from the leader is an assurance made to society that his power is not threatening; on the flipside, silence is worrisome" (1972: 86). At a detailed level, the parallel between the palavers of Guayaki Indians and parliamentary debates is striking: the idea is not to disseminate information, but rather to tirelessly repeat it while masking the repetition. "[...] a strange comedy where the listeners wore looks of surprise while paying attention to the one who, of course, could not be fooled by their feigned surprise" (1972: 84): Clastres' description of the relationship to the chief during discussions among Indians is uncannily reminiscent of the minister's position during parliamentary debates. Both the tribe and hemicycle display social comedy because of the need for ad libitum speech, which requires some cunning and some effects. The commonalities between the two situations are not accidental and take root on the moderating virtues of speech imposed on power.

Does the fact of imposing public speech on decision-makers have an impact on their decisions? Jon Elster famously answered affirmatively to this question in a comparison of the Constituent processes in France and in the USA (El- 
ster, 2000). His idea of a "civilizing force of hypocrisy" rests on two assumptions. Firstly, "[...] purely self-interested [actors] may have been forced or induced to substitute the language of impartial argument for the language of self-interest" (ibid: 372 ). Speakers tend to care about the way their views will be perceived by an audience beyond the members of the assembly. It would have been harder, for instance, to support slavery if the debates of the Convention of Philadelphia had been public. Secondly, Elster adds that "this substitution mattered for the outcomes" (ibid) which means that the views held during debates have some impact on the decisions made. When it is time to vote, members are partly constrained by the view they held during debates. Furthermore, the advantage of publicly acceptable claims during debates helps to narrow down the alternatives on which decisions should be made. This process operates for all participants in debates but is more constraining for the majority and its leaders. As later recognised by Elster (2011), the view that hypocrisy has a civilising power rather than, for instance, more conflict is dependent on the values seen as legitimate within a given society. Yet the general idea that the mere existence of debates makes the final outcomes closer to the median voters view still holds - whatever those views are. In addition, the obligation of self-justification during public debates produces anticipatory effects independently of the consequences of the speech on decisions. Suppose, for example, that a Prime Minister would like to implement a particularly unfair fiscal policy. It makes sense to assume that she will hesitate more to propose the related bill in a system that forces her to support it publicly. Empirical works coding debates according to the same grid, called Discourse Quality Index, confirmed this supposition, since justification tend be more developed in speeches during floor meetings than those within closed-door committees (Steiner et al., 2004: 128).

What is specific to parliamentarianism compared to traditional societies is based, secondly, on the fact that discordant voices are opposed to what the leader is saying. The leader not only has to soliloquise or converse through consensus, but he is also subjected to critique, to which he must listen and respond. Oppositional politics in parliament rely on voting, procedural tactics and the delivery of critical speeches. As Finlayson writes (2017: 21): "Opposition fundamentally involves the presentation, in debate, of 'good reasons' to reject the government position; it is a rhetorical activity". Oral addresses and questions are the most advanced form of this oral pluralism, but the legislative process also uses it by forcing the minister to give an opinion on each defended amendment (even if it means deferring to the assembly's wisdom). In any case, oppositional speech is protected by certain procedures and by the legal guarantee of broad immunity (Palonen, 2014). As mentioned above, the absence of any possibility of delegation - one does not have a speech read on the floor by another ${ }^{9}$ - facilitates the physical co-presence of opponents. The 
systematic organisation of confrontation through words is an age-old process that can be found in the figure of the jester and in the judicial process. Under the guise of the grotesque and of showmanship, the jester is the one who can and should speak the truth to the king. The judicial process operates on the basis of systematic opposition between stakeholders. Parliamentary debates are in the same vein: they provide a display of clashing positions, not in order to determine the truth (as for trials), but rather to relativise the position of the powerful.

While parliamentary debates do not seek the truth, they do contain a truth: that of anti-authoritarian relativism (Rozenberg and Thiers, 2018) ${ }^{10}$. By subjecting power to constant criticism, they are in parallel saying that this power's time is limited and that government results from a temporary electoral contingency. They bring home the distant prospect of forthcoming elections. They also express the idea that the electoral balance of power is not a sufficient basis for a reasoned point a view. Power must explain itself, justify itself through words and respond to criticism even if it has the means to dictate laws. In most cases, this accountability process does not directly affect the executive's political capacity. Indeed, the vote that follows parliamentary debate confirms the preexisting balance of power. However, besides the fact that texts do not remain unchanged after debates, what appears to matter most is that debates spread a democratic ethic through the institutionalisation of pluralistic political speech.

Comparative studies focussed on a special kind of debate - oral questions - provide empirical evidences for the constraining effects of antagonistic oral exchanges. Robert Salmond (2011) showed that the more the precise organisation of question time puts ministers in an uncomfortable situation, the less they tend to delegate their files to the administration. The fear for their reputation leads them to prepare the sessions in advance. In that case, the type of oral debates has an indirect impact on administrative discretion.

This is why the question of parliamentary language aesthetics is important: it involves showing society peaceful forms of interaction. If the parliamentary opposition refuses to speak or is prevented from doing so, as is the case when the so-called "guillotine" procedure is used, an impression of parliamentary dysfunction immediately arises. Finally, in some cases an issue raised in session can even cause a power to fall. For example, it was an official declaration in the House of Commons from Margaret Thatcher's former right hand that precipitated the resignation of the Prime Minister in 1990. Granted, this resignation had a numerical explanation (the number of conservative dissidents), but it took an oral performance during a session, in the sense of the performance studies mentioned earlier, to prompt it. 


\section{Conclusion}

In the end, it may be hypothesised that parliamentary debates express, without monopolising, our anthropological relationship to politics: that of men and women who gather to talk, excluding violence (Leca, 1973; Milner, 2011). Furthermore, analysis of the political discourse expressed in the hemicycle as self-referenced speech serving to contain the head rather than to transmit information follows the sociological interpretation of the evolution of human language. According to the famous analysis by Robin Dunbar (1996), language aims to maintain cohesion in big groups, and does so on a playful rather than utilitarian basis: gossip among friends is functionally comparable to delousing among apes. By "talking without saying anything" on the chamber's floor, MPs and ministers might be seen as reenacting this anthropological gesture at the level of representative democracies.

What is specific to parliaments is that such social finalities of political language are maintained despite the pluralism of the institution. Indeed, it has been established throughout the paper that debates in parliaments aim at provoking a confrontation of opposing views. The goal behind this is not, or no longer, to cause the decision-maker to weigh pros and cons (in order to make the best decision) but to frame the issues at stake and force accountability. Parliamentary debates strengthen social cohesion by putting political divisions into words. They therefore help to institutionalise the social conflict - a process that is at the heart of the functioning of representative democracy. A key aspect of this process can be noted in the procedural nature of many parliamentary speeches. Finlayson (2017: 26) writes: "Parliamentary debate is always debate about debate [...]". The civilising power of parliamentary debate, to allude to Elster, probably lies in the capacity of parliament to transform social cleavages into procedural conflicts through the virtue of public speeches.

To conclude, two limits should be mentioned regarding the virtues of parliamentary debates. Briefly, parliamentary debates are not virtuous in themselves, but require that both MPs and citizens play the game: the game of oral exchange for MPs and the game of listening for citizens. The first caveat regards the acceptable degree of pluralism acceptable, as for other parliamentary activities. Legislatures need their members to play the game of parliamentary politics, which means, regarding parliamentary debates, limiting filibustering tactics, agreeing to answer interpellations, listening to at least a minimal degree, etc. These behaviours cannot be taken for granted and lead to the classic problem of how democrats should behave toward non-democrats. As the question was raised rather early in European parliaments (often in the late 19th century), some procedural solutions for balancing efficiency in decisions and diversity and liveliness in debates were found. Greater centralisation of the 
agenda and a greater role for committees in legislative procedure were the two main solutions (Koss, 2018). The other limitation is more serious and relates to the general public's lack of interest for parliamentary debates. Some of the identified purposes of the debates can be achieved without a large audience, for instance the signals sent by MPs to party leaders through taking the floor. But most of them need at least a minimal external audience. The tribunal of public opinion needs (some) citizens to sit in it. Having become, in a way, fancy indigenous museums of Athenian democracy, parliaments in Europe provide a view, from the public gallery, of a certain of idea of politics that is threatened today.

\section{Endnotes}

1 The argument that institutions offer solutions to political problems might be surprising given the disqualification of problem-solving in post-positivist analysis of public policy. However, what distinguishes institutional problem-solving from illusory problem-solving in public policy is the nature of the issues involved: mainly exogenous for public action, and mainly endogenous for institutional design. In other words, while it is not clear that employment policies effectively seek to resolve the issue of unemployment, it is less doubtful that political organisations seek to resolve the issues that their very existence raises. Indeed, new institutionalist schools acknowledge that political actors can both be influenced by their organisations and seek to change these organisations' rules. In addition, institutional solutions are partial and often deficient, not least because they present actors with strategic trade-offs.

2 Moreover, session votes are rarely public in their entirety, unlike oral statements.

3 In this regard, the compromising effect of debate also enhances the stability of the collective decision by limiting the risk of contradictory cyclical majorities evoked in part one.

4 To give just one example, a book drafted in 2016 by a French new MP starts with this words: "My first entrance within the hemicycle was a very strong moment" (Nieson, 2016: 7).

5 With regard to the latter, the whips control over the list of speakers in session reinforces both voting discipline and the stability of collective decisions evoked in part one.

6 For a similar remark, see Finlayson (2017: 25)'s use of Jacques Rancière.

7 Provided that social movements stop at the doors of Parliament, which can never be taken for granted (Baudot, Rozenberg, 2011), forming an inherent weakness in the parliamentary age of representative government (Manin, 1995).

8 Because of space constraints, the comments in this last section mainly apply to the effects of parliamentary debates on established democratic regimes. However, several indicators suggest they can be generalised. The historiography of the past thirty years on 18th century French parliaments tends to understand parlia- 
mentary activities and rituals of the Old Regime as bargaining processes between elites (Swann, 2010). Thus, it is possible to identify "fragments of Republican discourse" in the admonishments of prerevolutionary assemblies (Lemaitre, 2010). Another example is the discussion over Standing Orders during a Syrian parliamentary session in 2003 showing that procedural formalism offered a specific resource to subtly thwart government action (Dupret et al., 2007).

9 Except, in France, for messages from the President of the Republic, given that the 5 th Republic is precisely characterised by the concentration of power in the presidency. In this regard the 2008 constitutional reform was controversial because it allowed the head of state to address the Congress (Rozenberg, 2012). The real problem here was not a matter of separation of powers, but rather, in line with our analysis, the fact that the president would have discretion over how often the procedure was used, and that he would be prohibited from witnessing the responses to his speech.

10 This does not mean that parliamentary debates are an insurance against dictatorship, as demonstrated by many historical episodes where docile assemblies granted full powers to a leader. Parliaments do not guarantee that a regime will remain democratic, but assuming they are able to debate with a certain degree of freedom, the likelihood of a dissenting voice, be it marginal, is high. In this regard, it is apparent in reading the report of the 10 June 1940 debates, which led the French National Assembly to give the reins to Maréchal Pétain, that the procedure was changed to prevent opponents of the constitutional law from airing their views.

\section{References}

BAUDOT, P.Y. and O. ROZENBERG, 2011. Désordres parlementaires. Introduction. Genèse, 83, 2-5.

BAYLEY, P., 2004. Introduction. In Paul Baylely (ed.) Cross Cultural Perspectives on Parliamentary Discourse. Amsterdam/Philadelphia: John Benjamins, 1-44.

BENTHAM, J., 2002. Political Tactics. Oxford: Oxford University Press, 1st ed. 1791.

BEST, H. and M. COTTA (eds.) 2000. Parliamentary Representatives in Europe 1848 2000: Legislative Recruitment and Careers in Eleven European Countries. Oxford: Oxford University Press.

BOURDIEU, P., 1981. La représentation politique. Éléments pour une théorie du champ politique. Actes de la Recherche en sciences sociales, 36-37, 3-24.

CARCASSONNE, G., 1993. De la démocratie au Parlement. Pouvoirs, 64, 35-41.

CLASTRES, P., 1972. Chronique des Indiens Guayaki: ce que savent les Aché, chasseurs nomades du Paraguay. Paris: Plon.

CLASTRES, P., 1989. Society Against the State: Essays in Political Anthropology. New York: Zone Books.

de Caritat marquis de CONDORCET, J.A. N., 1785. Essai sur l'application de l'analyse à la probabilité des décisions rendues à la pluralité des voix. In Condorcet, Sur les élections et autres textes. Paris: Fayard, 1986. 
CRES, H., 2018. L'approche économique des décisions d'assemblée. In O . Rozenberg and E. Thiers (eds) Traité d'études parlementaires. Bruxelles: Bruylant, 501-538.

DUNBAR, R., 1996. Grooming, Gossip, and the Evolution of Language. Cambridge Mass.: Harvard University Press.

DUPRET, B., S. BELHADJ and J.N. FERRIÉ, 2007. Démocratie, famille et procédure. Ethnométhodologie d'un débat parlementaire syrien. Revue européenne des sciences sociales, 45:139, 5-44.

ELSTER, J., 2000. Arguing and Bargaining in Two Constituent Assemblies. Journal of Constitutional Law, 2:2, 345-421.

ELSTER, J., 2011. Deliberation Cycles, and Misrepresentation, paper prepared for the Conference "Epistemic democracy in practice", Yale University.

ELSTER, J., 2013. Securities against Misrules. Juries, Assemblies, elections. Cambridge: Cambridge University Press.

ENELOW, J. M. and M. J. HINICH, 1984. The Spatial Theory of Voting: An Introduction. Cambridge: Cambridge University Press.

FERRIÉ, J. N., B. DUPRET and V. LEGRAND, 2008. Comprendre la délibération parlementaire. Une approche praxéologique de la politique en action. Revue française de science politique, 58:5, 795-815.

FINLAYSON, A., 2017. "What Is the Point of Parliamentary Debate?" Deliberation, Oratory, Opposition and Spectacle in the British House of Commons. Redescriptions, 20:1, 11-31.

GALEMBERT de, C., 2013. Alceste, un outil d'investigation de la fabrique parlementaire du droit. Quelques enseignements tirés de l'analyse des débats parlementaires à l'écriture du droit. In C. de Galembert, O. Rozenberg and C. Vigour (eds.) Faire parler le Parlement. Paris: Librairie générale de droit et de jurisprudence, 261-281.

GARDEY, D., 2013. "Enregistrer" et rendre les débats publics en Grande-Bretagne et en France. La sténographie comme exigence et révélateur de la démocratie parlementaire ? In C. de Galembert, O. Rozenberg and C. Vigour (eds.) Faire parler le Parlement. Paris: Librairie générale de droit et de jurisprudence, 7389.

GREENBERG, J., 1979. Consistent Majority Rules Over Compact Sets of Alternatives. Econometrica, 47:3, 627-636.

HABERMAS, J., 1984. Theory of Communicative Action. Boston: Beacon Press.

HEBERT, M., 2018. La voix du peuple. Une histoire des assemblées au Moyen Age. Paris: Presses Universitaires de France.

HEURTIN, J. P., 1999. L’espace public parlementaire: essai sur les raisons du législateur. Paris: Presses universitaires de France.

HIX, S., A. G. NOURY and G. ROLAND, 2007. Democratic Politics in the European Parliament. Cambridge: Cambridge University Press.

JENNY, M. and W. C. MULLER, 2012. Parliamentary Roles of MPs in Sharp and Soft Focus. In M. Blomgren and O. Rozenberg (eds.) Parliamentary Roles in Modern Legislatures. London/New York: Routledge, 145-161.

KOSS, M., 2018. Parliaments in Time. Legislative Democracy in Western Europe, 18662015. Oxford, Oxford University Press.

LECA, J., 1971. Le Repérage du politique. Projet, 71. 
LEMAITRE, A. J., 2010. Introduction. Fragments d'un discours républicain. In Le monde parlementaire au xviiie siècle: l'invention d'un discours politique. Rennes: Presses universitaires de Rennes, 9-16.

MCKELVEY, R. D., 1976. Intransitivities in Multidimensional Voting Models and some Implication for Agenda Control. Journal of Economic Theory, 12:3, 472482.

MANIN, B., 1997. The Principles of Representative Government. Cambridge: Cambridge University Press.

MANIN, B., 2011. Comment promouvoir la délibération démocratique? Priorité du débat contradictoire sur la discussion. Raisons politiques, 42:2, 83-113.

MAYHEW, D. R., 1974. Congress: The Electoral Connection. 1re éd., New Haven, CT/ London: Yale University Press.

MILNER, J.C., 2011. Pour une politique des êtres parlants. Court traité politique 2. Lagrasse, Verdier.

NAVARRO, J., 2009. Les députés européens et leurs rôles. Bruxelles: Éd. de l'Université de Bruxelles.

NIESON, N., 2016. La députée du coin. Paris, Seuil.

OFFERLE, M., (ed.), 1999. La Profession politique: $x i x^{e}-x x^{e}$ siècles. Paris: Belin.

PALONEN, K., 2014. The Politics of Parliamentary Procedure. Opladen: Barbara Budrich Publishers.

PIZZORNO, A., 2008. La sfera pubblica e il concetto di mandante immaginario. Sociologica, 3, 1-22.

PLOTT, C. R., 1967. A Notion of Equilibrium and its Possibility under the Majority Rule. American Economic Review, 57:4, 787-806.

POGUNTKE, T. and P. WEBB (eds.), 2005. The Presidentialization of Politics: A Comparative Study of Modern Democracies. Oxford, Oxford University Press.

PROKSCH, S.O. and J. B. SLAPIN, 2010. Position Taking in European Parliament Speeches. British Journal of Political Science, 40:3, 587-611.

PROKSCH, S.O. and J. B. SLAPIN, 2014. The Politics of Parliamentary Debate: Parties, Rebels and Representation. Cambridge: Cambridge University Press.

RASCH, B. E., 2014. On the Non-Deliberative Nature of Parliamentary Debates. In T. Raunio and H. Nurmi (eds.) The Serious Game of Politics. Tampere: The Finnish Political Science Association, 137-158.

ROUSSELLIER, N., 1997. Le Parlement de l'éloquence. La souveraineté de la délibération au lendemain de la Grande guerre. Paris: Presses de Sciences Po.

ROZENBERG, O., 2012. Nicolas Sarkozy législateur: la loi du plus fort? In J. de Maillard and Y. Surel (eds) Politiques publiques, 3. Les politiques publiques sous Sarkozy. Paris, 113-133.

ROZENBERG, O., 2013. Wisdom or Indifference? The Principles of Representative Government in the Eyes of the French Voters. Journal of Legislative Studies, 19:2, $196-218$.

ROZENBERG, O., 2018. Les députés français et l'Europe. Tristes hémicycles? Paris: Presses de Sciences Po.

ROZENBERG, O. and C. HEFFTLER, 2015. Introduction. In C. Hefftler, C. Neuhold, O. Rozenberg and J. Smith (eds.) The Palgrave Handbook of National Parliaments and the European Union. London: Palgrave Macmillan, 1-39. 
ROZENBERG, O. and S. MARTIN, 2011. Questioning Parliamentary Questions. Journal of Legislative Studies, 17:3, 394-404.

ROZENBERG, O. and E. THIERS, 2018. Du Parlement. In O. Rozenberg, and E. Thiers (eds) Traité d'études parlementaires. Bruxelles: Bruylant, 31-62.

SAALFELD, T., 2000. Members of Parliament and Governments in Western Europe: Agency Relations and Problems of Oversight. European Journal of Political Research, 37:3, 353-376.

SALMOND, R., 2011. Bureaucrats in the Headlights: Question Times and Delegation to Bureaucrats. Journal of Legislative Studies, 17:3, 368-381.

SCHECHNER, R., 2002. Performance Studies: An Introduction. London: Routledge.

SEARING, D. D., 1994. Westminster's World: Understanding Political Roles. Cambridge, MA: Harvard University Press.

SHEPSLE, K. A., 1979. Institutional Arrangements and Equilibrium in Multidimensional Voting Models. American Journal of Political Science, 23:1, 27-59.

SIEBERER, U., 2011. The Institutional Power of Western European Parliaments: A Multidimensional Analysis. West European Politics, 34:4, 731-54.

SLAPIN, J. B. and S.O. PROKSCH, 2010. Look Who's Talking: Parliamentary Debate in the European Union. European Union Politics, 11:3, 333-357.

STEINER, J., A. BACHTIGER, M. SPORNDLI and M. STEENBERGEN, 2004. Deliberative Politics in Action. Analyzing Parliamentary Discourse. Cambridge: Cambridge University Press.

STRØM, K., W. C. MÜLLER and T. BERGMAN (eds.), 2003. Delegation and Accountability in Parliamentary Democracies. Oxford/New York: Oxford University Press, 109-220.

SWANN, J., 2010. Repenser les parlements au xviii siècle: du concept de l'opposition parlementaire' à celui de 'culture juridique des conflits politiques. In A. J. Lemâ̂tre (ed.) Le monde parlementaire au xviiie siècle: l'invention d'un discours politique. Rennes: Presses universitaires de Rennes, 17-37.

TESTART, A., 2012., Avant L'histoire: l'évolution des sociétés, de Lascaux à Carnac. Paris: Gallimard.

VIGOUR, C., 2013. Réflexivité, rôle parlementaire et discours de légitimation. Les apports du logiciel Alceste à l'analyse lexicale d'un débat parlementaire relatif aux rapports entre justice et politique. In C. de Galembert, O. Rozenberg and C. Vigour (eds.) Faire parler le Parlement. Paris: Librairie générale de droit et de jurisprudence, 127-147.

VIKTOROVITCH, C., 2013. Parler, pour quoi faire? La délibération parlementaire à l'Assemblée nationale et au Sénat (2008-2012), unpublished PhD in political science, Sciences Po, Paris. 